\title{
Environmental Awareness in Ecotourism Destination Management in Mount Aso, Kumamoto, Japan
}

\author{
Jeffrey Stewart Morrow, PhD \\ Department of Environmental and Symbiotic Sciences Division of Environmental Resources Prefectural \\ University of Kumamoto 3-1-100 Tsukide, Higashi-ku Kumamoto, Japan 862-8502 Japan
}

\begin{abstract}
*Corresponding Author: Jeffrey Stewart Morrow, PhD Department of Environmental and Symbiotic Sciences Division of Environmental Resources Prefectural University of Kumamoto 3-1-100 Tsukide, Higashi-ku Kumamoto, Japan 862-8502 Japan
\end{abstract}

\begin{abstract}
Ecotourism has expanded remarkably over the past ten years; ecotourism destinations have also increased to match the demand of travelers interested in environmental and natural experiences. Ecotourism and sustainable tourism have been buzzwords of the past decade, and, as such, one expects that ecotourism destination employees would most likely possess awareness of local environmental aspects that can be translated into the tourism process. The author hypothesized that employees of tourism businesses in Mount Aso, Kyushu, Japan that have close proximity to natural settings would probably have a deep knowledge and awareness of the local environment and geological settings that are evident here. To investigate the question of environmental awareness in the area more fully, the author conducted a survey among tourism employees in order to examine their level of environmental awareness. Results found that the majority of employees had at least some knowledge of environmental sustainability, but many were not aware of the impetus of ecotourism.
\end{abstract}

Keywords: Ecotourism, sustainable tourism, environment, environmental awareness.

\section{INTRODUCTION}

Ecotourism has been growing remarkably during the past decade. There are now more ecotourism destinations than ever before, and the traveling demographic has expanded greatly. Tourist demand has also increased; many educated eco-travelers are traveling for educational purposes as well as enjoyment and recreation. Ecotourism and sustainable tourism have been buzzwords of the last decade. Although the two are used in a uniform fashion, in fact, the two phrases are not interchangeable, and many definitions exist for both. The International Ecotourism Society (TIES) defines ecotourism as: "responsible travel to natural areas that conserves the environment, sustains the wellbeing of the local people, and involves interpretation and education" (TIES, 2015).

The UNWTO explains sustainable tourism as a matrix of environmental, economic, and sociocultural aspects as found in the following definition: "Sustainability principles refer to the environmental, economic and socio-cultural aspects of tourism development. A suitable balance must be established between these three dimensions to guarantee its long-term sustainability" (WWF Global, 2017).

To this end, the importance of ecotourism and employees' environmental knowledge is incredibly important for tourist influx into a particular area, not only for the community development and economic growth, but also for extending environmental knowledge globally.

To extend knowledge and education to the traveling public, ecotourism destination employees and guides should possess in-depth knowledge of all the attributes and positive traits that a destination has to offer including background knowledge of flora and fauna activity, and other factors such as water usage, land conservation, controlled burning of grasslands, and natural disaster awareness and recovery. The hypothesis by the author was that those involved in geo, eco, and mass tourism in the area must have a knowledge of, an interest in, and motivation to learn and relay information to travelers, and therefore are probably knowledgeable about the ecology and history of the area. 
Section 1 introduces the topic, offers background information, and explains the author's impetus and objective for this research. Section 2 examines the method, the materials used, and also includes demographic information from the survey. Section 3 contains the results and a discussion of results. Section 4concludes, while section 5 offers ideas for further research.

\subsection{Kumamoto And Mount Aso Earthquakes}

This section explains the earthquakes that hit the area several years prior because theses earthquakes had an impact on the tourism redevelopment and subsequent interest in ecotourism in the area. In April of 2016 the two earthquakes that hit the active volcano area, Mount Aso, near the author's residence in Kumamoto, Japan were incredibly powerful and caused much damage, including communication constraints and obvious problems related to tourist influx.

The first earthquake occurred on April $14^{\text {th }}$ at 8:40 P.M. and the second came without warning in the early morning hours of April $16^{\text {th }}$. The quakes forced people to evacuate homes, close businesses, and in some cases, relocate to other areas of Japan. As Fig. 1 shows, the landslide that occurred during the second earthquake on April $16^{\text {th }}$, took down the large bridge in the area, called Aso Ohashi (Aso Large Bridge), which was a main connection thoroughfare into the Minami Aso Village area containing the volcano and surrounding caldera.

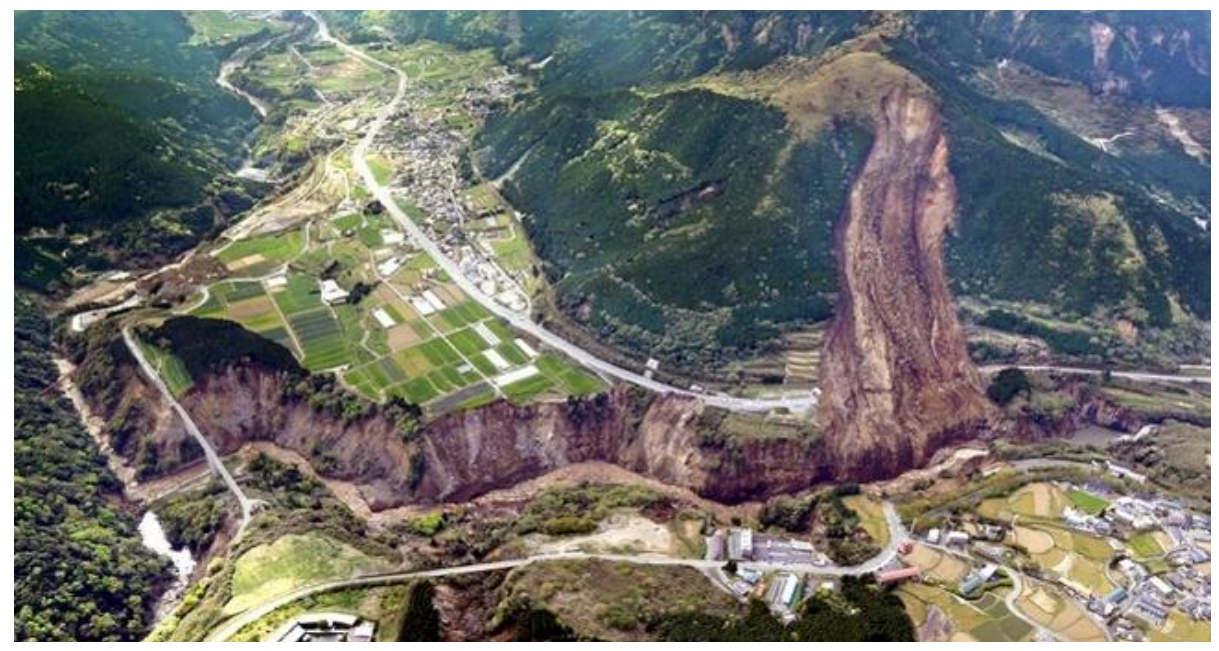

Fig1. Collapse of Aso Large Bridge "Ohashi"

Source: Photo by the Mainichi, 2016/4/22

\subsection{Impetus for Research}

The negative impact on tourism was also evident in data that showed a large drop in tourist numbers, and also in difficulties in spreading communication from government-based agencies and within local communities, especially effecting international residents currently living in the area. Figure 2 displays the total number of tourists to Kumamoto Prefecture in millions of tourists in the years 2008-2017. As can be seen, total tourists decreased in 2016 after the earthquakes.

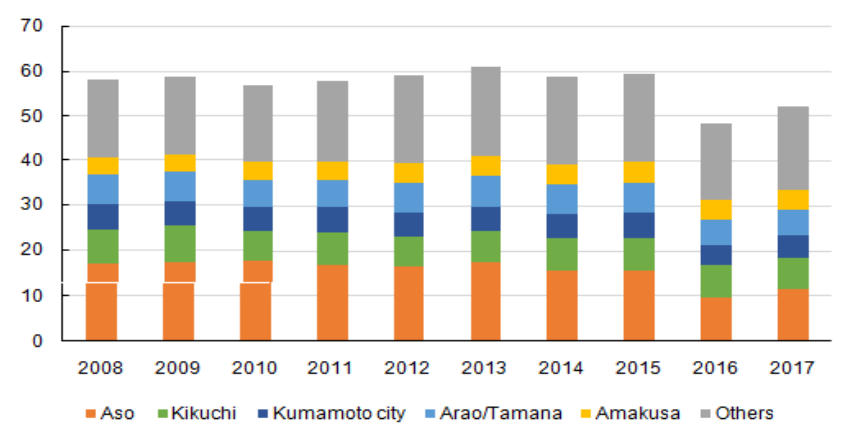

Fig2. Total Number of Tourists to Kumamoto Prefecture (in millions)

Source: Kumamoto Tourism Statistics, 2018.

Among stakeholders, the general consensus is that rebuilding Aso sustainably would be a notable and positive move, and also that making sustainable ecotourism destinations there is a worthwhile goal, 
and requires knowledge of environmental factors, training in ecology, observable conservation efforts, and motivation for environmental sustainability, all of which have received much attention globally recently.

Figure 3 shows the total number of foreign tourists to Kumamoto from 2008-2017. Foreign tourist influx dropped significantly after the 2016 earthquakes but rebounded in 2017. Tourists were mainly from China, Korea, and Vietnam.

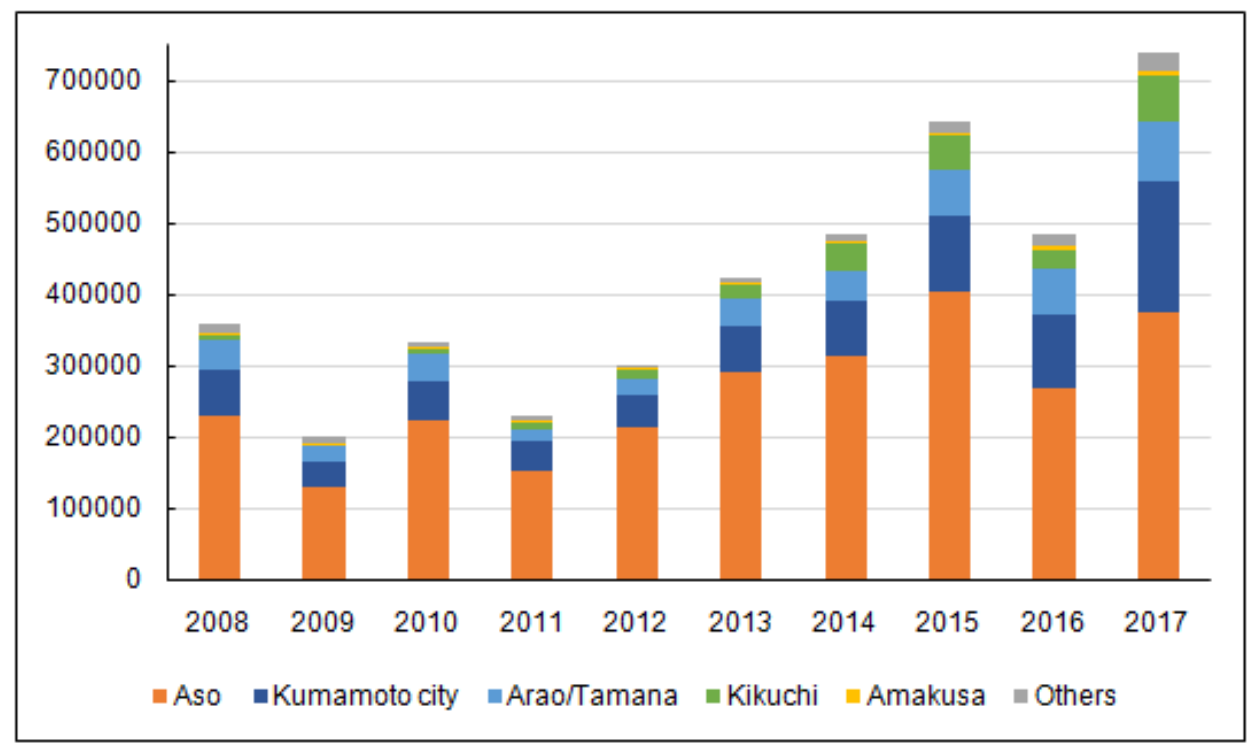

Figure3. Foreign tourists to Kumamoto.

Source: Kumamoto Tourism Statistics, 2018.

It is an obvious point that tourism business owners, managers, and employees, and guides should possess intimate knowledge of local areas in order to teach travelers. This includes local knowledge of cuisine, sightseeing attractions, and environmental aspects, which make an area unique. This can maintain hearty tourism businesses and attract more customers to any natural area in the future. However, the level of knowledge and awareness of the environment of employees of tourism related businesses in Mount Aso, which is within Aso-Kuju National Park, was unknown. Adequately understanding the level of environmental awareness of tourism managers and employees became the author's goal. Knowing both the plusses, and the shortcomings of knowledge which impacts teaching and impelling this knowledge to travelers is important because the assumption of late is that eco travelers are educated and want to learn as much as they can about the environment a particular area while having enjoyable experiences in nature. Aso-Kuju has great ecotourism potential but it is littleknown and gets few repeat customers. Why? To understand if environmental awareness and knowledge of geo and ecotourism around Mount Aso is lacking, a research study was conducted with managers, owners, frontline employees, and guides of local ecotourism and general tourism related businesses in the Kyushu area. The objective of the study was to examine the level of interest in the environment and awareness of environmental aspects in various areas Aso-Kuju, and in aspects that require slight study and knowledge such as aspects of geo-tourism and geopark history, land usage, animal husbandry, and agricultural aspects. The next section examines the method and instrument used in the study.

\section{Method AND MATERIALS}

In order investigate the question of environmental awareness among employees in Aso, the author and research team conducted a survey among 23 employees, managers, and owners working in tourism related businesses in the Aso area in November and December 2018 and March 2019.

The objective of the survey was to discover employees' underlying knowledge of the environment and interest in it, which has the potential to propel them on to further study and experience in eco and agri-based knowledge from agriculture to local flora and fauna. This study can assist employees in learning about all aspect of the area fully in order to adequately teach interested travelers, who have become more and more interested in Aso, geo-tourism, and local area ecotourism activities. These 
factors can help create viable and unique ecotourism destinations, starting with enthusiastic and knowledgeable staff, first, which can translate into interesting experiences for eco-travelers.

\subsection{Data Collection Method}

In order to do obtain sample information, in depth face to face interviews were conducted randomly with managers, owner, employees, and guides directly at places of businesses. Before conducting interviews, permission was asked of the business owner, manager on duty, or the overseeing body. After permission was granted, the research team chose respondents randomly by assigning numbers to the employees which were then drawn out of a hat. This was done to avoid biased answers. Following this, face to face interviews were conducted, and the interviews were recorded on portable IC recorders. In addition, the research team wrote answers from the respondents directly on the questionnaire after clarification with the respondent to avoid confusing answers. Random, distanced observations of employees by the research team was also conducted in order to watch the employees carry out activities such as taking orders, checking in guests, sales, guiding, explaining, and other general tourism-related duties.

\subsection{Materials}

To collect data, a questionnaire was used during face-to-face interviews. The questionnaire contained 25 background items such as age, gender, marital status, educational level, living situation, and city of birth. It also includes ecotourism/conservation-related questions such as: How familiar are you with environmental sustainability? How aware are you with the environment? How much do you participate in environmental conservation activities? How important is environmental sustainability to you? What does ecotourism mean to you?

Face to face interviews were conducted in various tourism-related areas in Mount Aso within AsoKuju National Park, in Kyushu, Japan. The areas in which surveys were conducted can be found in Fig. 4.

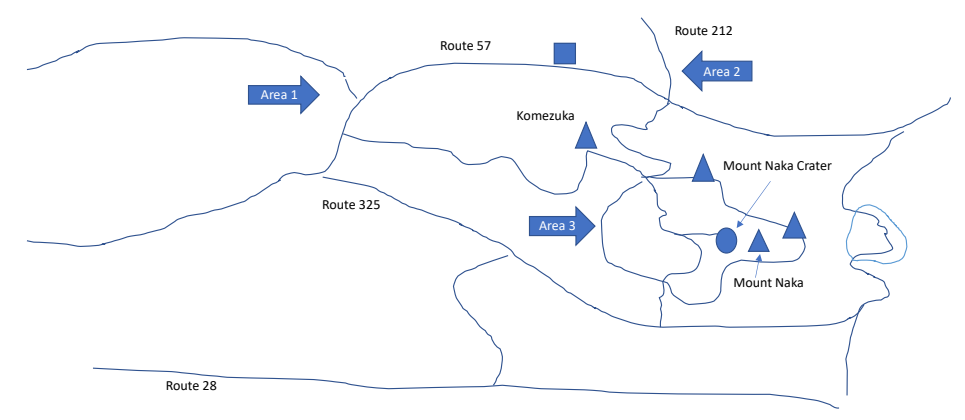

Fig4. Survey Areas of Mount Aso

Source: Derived from Survey Data, 2019.

\subsection{Demographic Information}

Post-questionnaire, demographic information was compiled into Table 1. Respondents totaled 23 employees of tourism related business types in central Mount Aso: restaurants, gift shops, hotels, and guesthouses. These businesses are located within Aso-Kuju National Park and have relation with ecology and the environment as many shops sell locally grown produce and offer meals of locally produced and harvested foods such as buckwheat noodles, mustard root, and locally raised beef.

The majority of respondents were male, 14 were married, 2 divorced; of those, 12 had children. Single respondents totaled 7. The majority (12 respondents) graduated from High School, while 5 had some university training, and 3 were university graduates. The respondents either lived alone, with their parents along with their wives or husbands with children, alone with wives or husbands and children, in a dormitory, or in another situation such as with a friend, alone in a hotel, or in a hotel with wife or husband along with children. Most respondents were born in the Aso area while several others were 
born in communities within a $25 \mathrm{~km}$ radius from Aso, in Kumamoto City, a $45 \mathrm{~km}$ distance from Aso, or in Amakusa Island chain, in southern part of Kumamoto Prefecture, a $70 \mathrm{~km}$ distance away.

Table1. Aso Demographic Information

\begin{tabular}{|c|c|c|}
\hline Sample size & & 23 \\
\hline Average age & & 36 \\
\hline Sex & $\mathrm{M}$ & 12 \\
\hline & $\mathrm{F}$ & 11 \\
\hline Total & & 23 \\
\hline Marital & $\mathrm{S}$ & 7 \\
\hline & $\mathrm{M}$ & 14 \\
\hline & $\mathrm{D}$ & 2 \\
\hline Total & & 23 \\
\hline Children & $\mathrm{Y}$ & 12 \\
\hline & $\mathrm{N}$ & 11 \\
\hline Total & & 23 \\
\hline Educational & Primary & 0 \\
\hline & JHS & 2 \\
\hline & HS Grad & 12 \\
\hline & Some Uni & 5 \\
\hline & Uni Grad & 3 \\
\hline Total & & 23 \\
\hline Living & Alone & 5 \\
\hline & W/Parents (\&hus., wife, child) & 4 \\
\hline & W/Wife,Hus.,Child & 7 \\
\hline & Dormitory & 5 \\
\hline & $\begin{array}{l}\begin{array}{l}\text { Other (w/friend, in } \\
\text { +hus., wife,ch.) }\end{array} \\
\end{array}$ & 2 \\
\hline Total & & 23 \\
\hline City of Birth & Aso & 7 \\
\hline & Ozu & 1 \\
\hline & Amakusa & 2 \\
\hline & Kumamoto & 3 \\
\hline & Other & 10 \\
\hline Total & & 23 \\
\hline
\end{tabular}

Source: Compiled from Survey Data, 2019.

\section{RESULTS AND DISCUSSION}

\subsection{Qualitative Results}

Following, results of both the qualitative survey and the Likert style survey questions will be offered and shown in tables with explanations following. Table 2 contains qualitative results based on questions aimed at the respondents regarding several aspects: how familiar employees are with environmental sustainability, employees' awareness of ecotourism in Mount Aso, employees' participation in environmental conservation, the importance of environmental sustainability to employees, and what ecotourism means to the employees.

Table2. Qualitative Questionnaire Results

\begin{tabular}{|l|l|l|}
\hline \multirow{3}{*}{$\begin{array}{l}\text { 1. How familiar are you with } \\
\text { environmental sustainability? }\end{array}$} & Very & 13 \\
\cline { 2 - 3 } & Somewhat & 7 \\
\cline { 2 - 3 } & Not at all & 3 \\
\cline { 2 - 3 } & Total & 23 \\
\hline \multirow{3}{*}{ 2. How aware are you of the environment? } & Very & 18 \\
\cline { 2 - 3 } & Somewhat & 5 \\
\cline { 2 - 3 } & Not at all & 0 \\
\cline { 2 - 3 } & Total & 23 \\
\hline \multirow{2}{*}{$\begin{array}{l}\text { 3. What do you do for environmental } \\
\text { conservation?* }\end{array}$} & Recycling & 12 \\
\cline { 2 - 3 } & Repurposing & 3 \\
\cline { 2 - 3 } & Saving water & 4 \\
\hline
\end{tabular}


Environmental Awareness in Ecotourism Destination Management in Mount Aso, Kumamoto, Japan

\begin{tabular}{|c|c|c|}
\hline & Saving electricity & 8 \\
\hline & Use bicycle or public trans. & 1 \\
\hline & Use env. friendly soaps \& detergents & 4 \\
\hline & Other & 1 \\
\hline & & $\begin{array}{l}* \text { (answers } \\
\text { overlap) }\end{array}$ \\
\hline \multirow{4}{*}{$\begin{array}{l}\text { 4. How important is environmental } \\
\text { sustainability to you? }\end{array}$} & Very & 15 \\
\hline & Somewhat & 7 \\
\hline & Not important & 1 \\
\hline & Total & 23 \\
\hline \multirow[t]{8}{*}{ 5. What does ecotourism mean to you?* } & Eating locally grown food \& produce & 2 \\
\hline & Having fun in nature & 8 \\
\hline & Playing golf or outdoor leisure activities & 1 \\
\hline & Hiking in nature to see natural sights & 4 \\
\hline & Mountain biking or other adventure sports & 1 \\
\hline & Camping in natural spots & 1 \\
\hline & Learning about nature & 13 \\
\hline & & $\begin{array}{l}* \text { (answers } \\
\text { overlap) }\end{array}$ \\
\hline
\end{tabular}

Source: Compiled from Survey Data, 2019.

Findings show that most of the employees are very familiar with environmental sustainability, are aware of the environment, and feel that environmental sustainability is very important to them. All of the respondents participate in conservation efforts such as recycling, saving electricity, saving water, using environmentally friendly soaps and detergents, saving water, and using bicycles or public transportation. Many people felt that ecotourism simply means learning about nature. When asked, they did not disclose how they had fun in nature and how that connected to ecotourism; whether they played in parks, at recreation areas, or walked along trails or beaches was not known. Several respondents felt that ecotourism means hiking to see natural spots, while three felt that playing golf, mountain biking, or camping meant ecotourism to them.

\subsection{Likert Scale Results}

As mentioned earlier, a Likert-style questionnaire was also used to gather opinions of tourism-related items among business owners and managers in the Aso area. Table 3 shows results of the Likert scale questionnaire.

Table3. Likert Scale Results

\begin{tabular}{|c|c|c|}
\hline \multirow{6}{*}{$\begin{array}{l}\text { 1. Mount Aso is interesting, dynamic, and a } \\
\text { strong ecotourism industry can be achieved there. }\end{array}$} & Strongly agree & 9 \\
\hline & Agree & 12 \\
\hline & Neutral & 2 \\
\hline & Disagree & 0 \\
\hline & Strongly disagree & 0 \\
\hline & Total & 23 \\
\hline \multirow{6}{*}{$\begin{array}{l}\text { 2. I am prepared to study more to be able to teach } \\
\text { travelers about the environment there. }\end{array}$} & Strongly agree & 3 \\
\hline & Agree & 10 \\
\hline & Neutral & 6 \\
\hline & Disagree & 4 \\
\hline & Strongly disagree & 0 \\
\hline & Total & 23 \\
\hline \multirow{6}{*}{$\begin{array}{l}\text { 3. I always get enough information about Mount } \\
\text { Aso, the environment, and ecotourism, and hear } \\
\text { from tourists. }\end{array}$} & Strongly agree & 0 \\
\hline & Agree & 3 \\
\hline & Neutral & 8 \\
\hline & Disagree & 10 \\
\hline & Strongly disagree & 2 \\
\hline & Total & 23 \\
\hline \multirow{6}{*}{$\begin{array}{l}\text { 4. Creating ecotourism destinations can generate } \\
\text { employment and income opportunities for young } \\
\text { people in the area. }\end{array}$} & Strongly agree & 17 \\
\hline & Agree & 3 \\
\hline & Neutral & 3 \\
\hline & Disagree & 0 \\
\hline & Strongly disagree & 0 \\
\hline & Total & \\
\hline
\end{tabular}




\begin{tabular}{|l|l|l|}
\hline 5. Mount Aso has fresh water, good local foods, & Strongly agree & 16 \\
\cline { 2 - 3 } and can offer products and services for travelers, & Agree & 4 \\
\cline { 2 - 3 } thereby elevating the local economy. & Neutral & 3 \\
\cline { 2 - 3 } & Disagree & 0 \\
\cline { 2 - 3 } & Strongly disagree & 0 \\
\cline { 2 - 3 } & Total & 23 \\
\hline
\end{tabular}

Source: Compiled from Survey Data, 2019.

As can be seen in the table, most respondents agreed that Aso is an interesting and dynamic destination rich in ecology and can be promoted as a tourist destination now and in the future. Tourists' needs can be taken into account at a future time, in order to understand which aspects of green or environmental tourism influence travel behavior. In addition, most respondents felt they were more interested in preparing to study, learn, and train more in order to create a thriving ecotourism industry that can generate future employment and income opportunities. However, most respondents disagreed that they receive enough information on Mount Aso, the surrounding environment, and ecotourism which includes hearing news from tourists themselves. This is probably because an agenda for creating ecotourism destinations has not been fully agreed upon by the community nor land or agricultural stakeholders. As for creating ecotourism destinations for travelers now and in the future, many felt that creating ecotourism destinations in the future can help generate more interesting and more in-depth ecotourism destinations that may benefit young jobseekers economically and socially long into the future.

\subsection{Discussion}

Through face-to-face interviews, the study found that the majority of employees and owners participate in conservation efforts such as recycling; however, many are not fully aware of the recent trends in ecotourism. They do, however, possess some knowledge of sustainability and its significance in ecotourism and want to increase their own environmental awareness and knowledge. Even though the sample was small, this research showed that most employees had feelings of natural and the environment. In fact, these results show that all 23 of the employees had experience working in and around tourism and ecotourism but many still are not fully aware of the meaning of ecotourism, and as such, take less interest in its development. This is probably due to the fact that many of them had been working in tourism for many years and had come to work in ecotourism quite by accident so had no real basis on which to base knowledge and experience, which could be due to lack of education about the surrounding environment and its impact on would-be travelers who may find the location interesting.

Results of this research also show that employees were mostly very aware of sustainability and environmental spects, although connecting these with tourism is less apparent. As for acting in conservation, some act in recycling weekly, save electricity daily, and use environmentally friendly soaps and detergents. These aspects are probably fundamental in Japan, but may not be in other countries, so this research can show that it is important in the long run. All of the respondents reported that environmental sustainability is very important, even though many have not taken the notion seriously in their lives.

As for ecotourism, some think the meaning is simply playing in nature rlearning about nature, but it is much more than that in reality, as most global stake holders know. Perhaps through research such as this, more business owners, managers, and employees will be able to take their knowledge to the next level.

Table 2 which contains the Likert items shows that most respondents are aware of the environment, and want to take measures for conservation, participate in at least some recycling efforts, and are active in such activities as separating trash and repurposing things now and into the future. It was good to see that most respondents strongly agreed that the Mount Aso area is dynamic and interesting, are that they prepared to teach aspects about the environment. In addition, the fact that they agree creating ecotourism destinations is positive for young people, and that Aso products and services can be available more globally, with enhanced promotion. The promotion of Aso-related ecotourism activities and local products also has the potential to elevate income is a very positive sign for further ecotourism development in Aso economically. This is an encouraging sign, and it is important the employees themselves feel an ecotourism destination could be established there; however, in many cases there is much discussion and little action. 


\section{CONCLUSiON}

The answers of the respondents in both qualitative and Likert questionnaires reflect the point that some respondents do not see the positivity in creating endeavors such as creating an interesting and dynamic eco-tourism destination situation. The author attributes these feelings of neither agreeing nor disagreeing to the fact that many people have little or no knowledge of the environment, little training in environmental topics, or little interest in elevating the environment or learning about ecotourism, and because of this, they can neither agree nor disagree with the item fully. This taken into account, it can be surmised from the survey data that all in all, most respondents feel that Aso environment is beautiful and worthy of teaching its unique features to international travelers and community members. However,inordertodoso,employeesneedtohavebackgroundknowledgeof ecotourism, tourism in general, agriculture, local flora and fauna, and also must possess communication skills to put fort hide as fully. The majority think that because of its beauty international travelers would want to visit Aso if they knew more about it, and in fact, while Internet information is growing, overall information about the area in general still lacks. Respondents also stated that they want to help elevate interest in nature with environmental conservation, and to further promote the environment of Aso and its environs. The respondents primarily want to further ecotourism and environmental training by helping employees learn more about ecotourism and become more aware of it so they can teach travelers more about Aso and surrounding areas. This includes reaching out to the community in order to create exciting and interesting ecotourism opportunities, and also increasing travelers' as well as local communities members' knowledge about Aso-Kuju. To this end, it can be said that the author's hypothesis, that tourism employees probably have much knowledge about the surrounding eco and geo related aspects as well as the motivation to learn and teach more cannot be fully accepted.

\section{FURTHER RESEARCH}

To more fully examine the question of environmental awareness in ecotourism destinations and how this can be generated into further knowledge of tourism managers and employees, the author and research team will formulate other questionnaires for other businesses around the Aso-Kuju National Park area. In addition, the team will create ideas on how to teach these aspects to employees and staff adequately and fully. To follow this, the team will create tourism informational materials to help employees, staff, and guides to communicate in English and other languages more effectively. It goes without saying that feedback from international tourists is of utmost importance in creating effective and thoughtful information in ecotourism destinations. To this end, we will conduct surveys with international and domestic tourists to gather their perceptions of environmental knowledge and also to examine their levels of satisfaction. This will better help us understand how to create the best possible information in interesting and dynamic ecotourism destinations that will hold long into the future.

\section{REFERENCES}

[1] City Population. (2018). Kumamoto City population. Retrieved December 4, 2018 from https://www. citypopulation.de/php/japan-kumamoto.php? cityid $=43100$

[2] Kumamoto Prefecture. (2018). Kumamoto Prefecture Tourism Statistics Table. Heisei 28. P.24.

[3] Mainichi. (2016). Aerial photograph of Ohashi collapse. Retrieved December 22, 2018 from https://mai nichi.jp/english/articles/20160422/p2a/00m/0na/026000c

[4] The International Ecotourism Society. (2019). What is ecotourism? Retrieved November 17, 2019 from https://ecotourism.org/what-is-ecotourism/

[5] World Wide Fund for Nature. (2018). What is the difference between ecotourism and sustainable tourism? Retrieved October 13, 2018 from http://wwf.panda.org/what_we_do/how_w+\&e_work/our_global_goals/ oceans/solutions/reducing_tourism_impact/difference_between_ecotourism_sustainable_tourism.cfm.

Citation: Jeffrey Stewart Morrow. "Environmental Awareness in Ecotourism Destination Management in Mount Aso, Kumamoto, Japan". International Journal of Research in Tourism and Hospitality (IJRTH), vol 7, no. 1, 2021, pp. 01-08. doi: https://doi.org/10.20431/2455-0043.0701001.

Copyright: () 2021 Authors. This is an open-access article distributed under the terms of the Creative Commons Attribution License, which permits unrestricted use, distribution, and reproduction in any medium, provided the original author and source are credited. 